\title{
EXPLORING THE INTERDEPENDENCE BETWEEN VISUALLY IMPAIRED AND SIGHTED PEOPLE IN THE EARLY PHASE OF FRIENDSHIP
}

\author{
Tabah Aris Nurjaman \\ Faculty of Humanities, Universitas Teknologi Yogyakarta
}

\begin{abstract}
A person with visual impairment must resist anatomic, social, and cultural obstruction thus requiring other individuals to complete the activities that require a sense of sight. This situation encourages them to establish relations of friendship with sighted people, which is considered to be always present in whenever needed help. The existence of aid distribution indicates the idiosyncrasies of friendship between visual impairment and sighted people, as also indicates a tendency of dependencies. Thus, this study aims to explore the relationship patterns of interdependence in the early phase of friendship. This study used a qualitative method with descriptive phenomenology approach. This study uses in-depth interviews at the data collection stage involving six research informants; or three couples of friends. The credibility of the research uses the triangulation (significant other) and member checking. The underlying aspects of the establishment of friendship in the study include contact, appraisal, and instrumental activity assistance on the visually impaired party; as well as contact, attractiveness, and instrumental aid distribution on the sighted party. The aspect of instrumental aid distribution is idiosyncratic in this friendship. Frequentative instrumental aid distribution indicates the tendency of dependence on visually impaired party, as well as reflecting the entity of help on sighted party which directs the interdependence pattern relationship. Periodic instrumental aid distribution indicates the tendency of independence on visually impaired party, as well as reflecting the entity of altruism on sighted party which directs the independence pattern relationship.
\end{abstract}

Keywords: interdependence, friendship, visual impairment.

\section{Introduction}

The globalization era does not guarantee the success of disability concept socialization. In fact, most people still consider disability through the mythological, medical, and anatomical lens (Phuspita 2010; Thohari, 2014; Untari \& Mayasari, 2015). As a result, persons with disabilities is seen as a group that needs help, to be pitied, poor, incompetent, and does not have the capability (Cuddy, Fiske, \& Glick, 2008; Hallahan \& Kauffman, 2006). Thus, the practice of discrimination, injustice, and even the tendencies that lead to dehumanization still The conditions got a response from persons with disabilities by making social models of occur (Haslam, 2006; Irwanto, Kasim, Frances, Lusli, \& Okta, 2010).

\footnotetext{
* Corresponding author: Tabah Aris Nurjaman

tabah.aris.n@gmail.com

Published online at http://IJDS.ub.ac.id/2018

Copyright @ 2018 PSLD UB Publishing. All Rights Reserved
}

Received, May $7^{\text {th }}, 2018$ disability, as desegregation efforts against them. This model considers that the inability of persons with disabilities in all aspects of life not because of physical or mental limitations, but the social system that still marginalize them as the minority who can not afford (Altman, 2001; Carson, 2009; Shakespeare \& Watson, 2002).

This discrepancy between the ideal desire of persons with disabilities and the actual condition attracted the attention of stakeholders the power to issue rules on the rights of persons with disabilities. However, their social system disequilibrium complicates the implementation of these rules so that the desegregation of the persons with disabilities be difficult to realize. This condition can be seen from the lack of accessibility for persons with disabilities, such as sanitation facilities, transportations, public services and infrastructure that is less friendly 
to them (Irwanto et al., 2010; Thohari, 2014). Likewise, with inclusive education does not guarantee the elimination of segregation and exclusivity. The condition is caused because there are still those who maintain binary logic, so assume that persons with disabilities should be educated exclusively (Thohari, 2014). The proof, inclusive education still leaves a gap practice injustice against people with disabilities, such as violence (Gur \& Albayrak, 2015), intimidation (Pinquart \& Pfeiffer, 2011b), social isolation (Hodge \& Eccles, 2013), rejection from peers (Khurshid \& Najeeb, 2012), as well as the exclusivity and discrimination (Mahabbati, 2014).

Conclusions from the discussion above indicate lack of advocacy for persons with disabilities; and on the other hand, promoted inclusive education to bridge the existing discrepancy still leaves the side of injustice. This situation shows the urgency, as well as the need for exploratory studies to investigate the relationship of persons with disabilities and non-disabled. Theoretically, these relational problems can be minimized through the implementation model of the contact hypothesis, offered by Allport more than half a century ago, as a trimmer prejudice at the group level (Pettigrew, 1998). Empirically, the implementation of contact is not only able to reduce existing prejudices (Vezzali \& Capozza, 2011), but also may open space for mutual understanding between the physical diversity of persons with disabilities and non-disabled people (Sulla, 2011).

In general, the most relevant contacts model to be explored is friendship (see Grass 2010; Sulla, 2011). Dwyer (2002) explains that the friendship is a relationship that is built on the basis of sincerity individual to another individual, because of the factor of proximity, similarity, physical attraction, reciprocal, complementary, and competent. Gilovich, Keltner, and Nisbett (2011) adds that the proximity factor was limited to bring two or more individuals passively (passive contact) so that one party should greet first so that friendships can be built. According to Berscheid and Ammazzalorso (2003), emphasis on interpersonal relations lies in the interaction. A pair of individuals said to interact if both parties mutually influence each other (interdependence). Rusbult, Arriaga, and
Agnew (2003) mentions four arguments underlying the importance of the study of interdependence in interpersonal relationships. First, interdependence forming daily interactions. The pattern of interdependence describes the constraints and the opportunity to detect interactions that are harmonious, contradictory or exploitation. Second, the interdependence of individual mental shape cognition and affection, which reflects the sense of interdependence situation to identify behaviors that will appear in the same situation. Third, establish a relationship of interdependence. Interdependence describes the options and limitations on a relationship, determined through commitment, trust, power, and conflict. Fourth, interdependence shape itself. Individual preferences are developing stability, motives, and behavioral tendencies as a consequence of adaptation to situations interdependent.

Van Lange and Rusbult (2012) asserts that the central theme of interdependence theory is social interaction. Interactions (I) is a relation of the needs, thoughts, motives, and behavior between two individuals (A and B) in specific situations (S), as formulated $\mathrm{I}=\mathrm{f}(\mathrm{S}, \mathrm{A}, \mathrm{B})$. At the level of analysis, there are at least three things to consider when trying to predict the pattern of interaction between two individuals. First, what is the situation when the interaction occurs? For example, A has a greater power than B. Second, how the needs, thoughts, and motives of individuals A when interacting with B. Third, how the needs, thoughts, and motives of individual $\mathrm{B}$ when interacting with $\mathrm{A}$. The result of this interaction is based on degrees satisfaction: Does the interaction led to the fulfillment of requirements, such as a feeling of comfort, or even slow him down? The results of these interactions are categorized into concrete and symbolic outcomes. The concrete outcomes are the satisfaction or dissatisfaction that is felt directly by individuals, while the symbolic outcomes is a consequence which is based on the wider implications.

The importance of research on friendship than other types of relationships based on four empirical argumentation. First, the problem in people with disabilities are at a relational level, such as social interaction (Celeste, 2006); social acceptance (Khurshid \& Najeeb, 2012); integration of groups and build relationships 
with other individuals (Pfeiffer \& Pinquart, 2011). Second, the two sides have parity on aspects of interest (Khadka, Ryan, Margrain, Woodhouse, \& Davies, 2012), thus opening up the possibility of a cooperative and collaborative interaction (Meriyani, 2013). Third, the benefits of friendship are quite significant for persons with disabilities, such as assistance in practice (Morrison \& Burhman, 2009); feel understood and protected (Asbjornslett, Engelsrud, \& Helseth, 2011); gaining full acceptance and increased confidence (Schuh, Sundar, \& Hagner, 2014); and gain the appreciation and the opportunity to develop social skills and express themselves (Dietrich, 2005). Fourth, at the level of relations between groups, friendship between individual non-disability and persons with disabilities can reduce bias in the group and anxiety among groups (see Levin, Laar, \& Sidanius, 2003; Page-Gould, Mendoza-Denton, \& Tropp, 2008), as well yielded positive attitude (see Munniksma, Stark, Verkuyten, Flache, \& Veenstra, 2013). However, the study of disability stresses the importance of the specification (Shakespeare \& Watson, 2002).

The friendship between people with disabilities and people of non-disability are dyadic, which is determined based on common interests between the two sides demonstrated through togetherness in activity (Dietrich, 2005; Morrison \& Burhman, 2009), although persons with disabilities receive more aid (Richardson, 2002). At this level, people with disabilities who often have difficulty in establishing a friendship is visual impairment. This view is based on the significance of the sense of sight in their interaction (Brown, Packer, \& Passmore, 2013; Celeste, 2006; Roe, 2008), which may specify other individual interest (Rosenblum, 1997). They were not able to detect and respond to a nonverbal language other persons, such as eye contact, hand gestures, and facial expressions (Rosenblum, 1997). This is reinforced by the findings of other studies, that the absence of a sense of sight to the visual impairment people have an impact on the reduction of social networking and the opportunity to establish contact with other individuals (Wang, Chan, Ho, \& Xiong, 2008). On the other hand, precisely the visual impairment people really need a lot of friends, as a major source of social support; compared with other physical disabilities gain more social support from parents (Senicar \& Grum, 2012). Thus, this exposure indicates the high importance of friendship for people with visual impairment than the other physical disability.

Friendship is one of the most dominant psychological need for people with visual impairment (Herlina, Heryati, \& Chotidjah, 2008). However, anatomical obstruction prevents them from social integration, so the opportunity to build friendships become slightly (Pfeiffer \& Pinquart, 2011). This situation is not only due to their difficulty in interacting (Brown et al., 2013; Celeste, 2006; Roe, 2008; Rosenblum, 1997), but also they are less able to open up and resolve interpersonal conflict (Ayomi, 2009), less satisfied with body image (Pinquart \& Pfeiffer, 2012), and overprotective parents who restrict their mobility (Khadka et al., 2012; Pinquart \& Pfeiffer, 2011a). Thus, the blindness requires them to adapt to functional limitations sense of sight, as well as a manifestation of self-acceptance on their blindness (Stevelink, Malcolm, \& Fear, 2015).

The friendship between visual impairment and sighted individuals tend to be asymmetrical. This view is based on two empirical and theoretical arguments. First, friendship is often viewed as a distribution of aid for persons with disabilities (Richardson, 2002). As they gained more aid, then the resulting dependence on the friendship (see Ainsworth, 1969; Nadler, Halabi, HarapzGorodeisky, \& Ben-David, 2010). Second, the tendency of visual impairment people as the party dependent on other individuals (Broman et al., 2002; Camarena, 2013; Good, Logrow, \& Alpass, 2008), as a consequence of the constraints of the social environment and the lack of accessibility (Hwang et al., 2015; Irwanto et al., 2010; Thohari, 2014). Thus, this exposure indicates the possibility of dependency on visual impairment people towards his friendship with the sighted.

Rusbult, Agnew, and Arriaga (2012) explains that the degree of dependency on individual needs and dependence on a relationship to get results. In this context, three psychological processes make people become the dependent party in a relationship (Rusbult et al., 2012). First, the degree of dependency is determined based on the individual's relationship satisfaction. Second, the degree of dependency is determined based on the volume 
of individual investments on the relation. Third, when the investment increases dependency, it will produce a commitment. The level of commitment determines the sustainability of long-term relationships. Essentially, individuals assign to the partner's behavior. When the partner's behavior is more focused on shared interests rather than personal interests, the degree of satisfaction, investment, and commitment of individuals tend to increase. The psychological process is in line with the study of interdependence, that the individual is a party dependent on an asymmetrical relationship is not only determined by the subjective aspects such as love and commitment but also differences in material resources which are distributed in the investment (Kelly et al., 2003).

Blindness research on the relational level is pretty much done. However, such studies involving children, such as communication patterns (Herrera, 2015; Cascella, Trief, \& Bruce, 2012), social interaction (Celeste, 2006; Jindal-Snape, 2005a, 2005b), and interpersonal competence (Ayomi, 2009). There is also a study of visual impairment people teenager, who studies courtship (Fichten, Goodrick, Amsel, \& McKenzie, 1991; Murniasih, 2004), social interaction between persons with visual impairment (Meriyani, 2013), and comparative orientation of the friendship between the visual impairments since birth with a group of visual impairment people who've seen (Herlina et al., 2008). Based on the discussion of blindness, which was presented earlier, the relational studies required in the contemporary era is the friendship between visual impairment with sighted people. Rosenblum (1997) and Lifshitz, Hen, and Weisse (2007) that has been researching this sector, but they are less relevant findings to be applied in Indonesia. This opinion is based on the findings of a study comparing reactions to persons with disabilities between collective and individualistic culture (Crystal, Watanabe, \& Chen, 1999; see Wang et al., 2008). Besides, the emergence of decontextualization at Rosenblum study (1997) showed the importance of reconstructing the model of friendship in visual impairment with sighted people, as well as indigenization toward indigenous psychology. At this level of analysis, assessment Rosenblum (1997) and Lifshitz and colleagues (2007) is not intended to explore patterns of interdependence, which although some studies have shown a tendency dependencies on this friendship.

This discussion led to the urgency of friendship visual impairment study while indicating the possibility of their dependency on the pair sighted friends. However, the use of the term dependencies in disability studies had been the subject of discussions among academics. Most academics suggested replacing the term dependency as a negative connotation to the term interdependence (see Fine \& Glendinning, 2005). But on the other hand, a portrait of reality can not be manipulated, that empirically visual impairment people are still dependent on other people. By weighing both sides, this study used the term interdependence which is considered a more flexible relationship between patterns of independence, dependence, and interdependence. Thus, this study aims to explore the interdependence between visually impaired and sighted people in the early phase of friendship.

\section{Method}

The author considers that the purpose of this study can be answered through a qualitative method with descriptive phenomenology approach (see Creswell, 2014; Willig, 2008). The selection was based on the argument that to explore the interdependence between visually impaired and sighted people in the early phase of friendship; it is necessary to search their intentionality in defining the phenomenon of friendship (see Moustakas, 1994).

This study chose Daerah Istimewa Yogyakarta (DIY) as a research location. The choice of location is based on the Riset Kesehatan Dasar (Riskesdas) in 2013, that average person with a disability in Yogyakarta has the lowest disability scores than persons with disability in all provinces of Indonesia (Kementerian Kesehatan [Kemenkes], 2014). Based on this exposure, the visual impairment people in Yogyakarta tend to have many opportunities to participate in society, so the probability of interaction between them and sighted people become larger. 
Tabel 1 . Informant Research Overview

\begin{tabular}{|c|c|c|c|c|c|c|}
\hline \multirow{2}{*}{ No } & \multirow{2}{*}{$\begin{array}{c}\text { Fake } \\
\text { Name }\end{array}$} & \multirow{2}{*}{ Gender } & \multicolumn{2}{|c|}{ Age (in years) } & \multirow{2}{*}{$\begin{array}{c}\text { Academic } \\
\text { Status }\end{array}$} & \multirow{2}{*}{ Blindness } \\
\hline & & & Informant & Friendship & & \\
\hline 1 & Wawan & Male & 24 & \multirow[b]{2}{*}{$41 / 2$} & Bachelor & Low - Congelital \\
\hline 2 & Hilal & Male & 23 & & $\begin{array}{c}\text { Undergraduate } \\
\text { Student }\end{array}$ & - \\
\hline 3 & Bowo & Male & 20 & \multirow{2}{*}{2} & $\begin{array}{c}\text { Undergraduate } \\
\text { Student }\end{array}$ & $\begin{array}{c}\text { Total - } \\
\text { Age } 15 \text { Years }\end{array}$ \\
\hline 4 & Dul & Male & 20 & & $\begin{array}{c}\text { Undergraduate } \\
\text { Student }\end{array}$ & - \\
\hline 5 & Pak RT & Male & 27 & \multirow{2}{*}{3} & $\begin{array}{c}\text { Undergraduate } \\
\text { Student }\end{array}$ & $\begin{array}{c}\text { Total }- \\
\text { Age } 7 \text { Years }\end{array}$ \\
\hline 6 & Anggi & Male & 21 & & $\begin{array}{c}\text { Undergraduate } \\
\text { Student }\end{array}$ & - \\
\hline
\end{tabular}

The study involved six research informants; three pairs of friends (Table 2.1). The whole informant has male sex. Five of their status as undergraduate students at Sunan Kalijaga University (UIN), whereas only an informant who has a degree from the same university. Based on the type of blindness, two blind people in total and one low visual impairment, with different backgrounds. Based on the characteristics of friendship, the two couples friends status as a student in the same faculty and forces, so often studied in the same class. While a couple of other friends formed because of a neighbor situation. The mean age of friendship to all research informants pairs, starting from the first meeting, was three years and two months. Based on the initial introduction, the two friends pair first met and exchanged greetings in the boarding residence; while the other pair occurred while running joint academic activities. In this situation, greeting occurred in two couples preceded by the sighted, while the other pair instead. Characteristics of friendship will be the focus of the analysis in the next section of research findings, with dyadic analysis.

This study also included three additional informants, which is intended for data validation. Selection of additional informants is based on the willingness and recommendation from each pair of informants friends. Overall, they are male and undergraduate student. Two of them are classmates of the two main informant friend's partner. One other additional informant was a friend of the boarding house of a friend's partner informants.

This study uses in-depth interviews to collect data. This interview is open and aimed to understand the experience of friendship. The author acts as a research instrument in collecting data through interviews and data analysis. This study uses the member checking, triangulation strategy (significant other), and transferability as the credibility of the strategy research (see Creswell, 2014; Willig, 2008). Meanwhile, research using informed consent as research ethics, which outlines no deception, right to withdraw, debriefing, and confidentiality (see Willig, 2008).

\section{Research Findings}

The friendship between visually impaired and sighted people constructed through three psychological aspects on each side. On the visually impaired party, this relationship can arise when he came into contact with the sighted party, which then directs him to make an appraisal through the attribution characteristics and identity recognition sighted partner. Contacts and appraisal are sufficient as an indicator of friendships, but a blindness as idiosyncratic of friendship leads instrumental aid amplifier existence of relations. On the sighted party, contact becomes aspects that open attractiveness to know visually impaired party. However, attractiveness on the sighted party will not necessarily be based on the characteristics of the blind couple, but can also arise because of the curiosity of disability world. Thus, both of these aspects will encourage them to be willing to distribute instrumental aid to visually impaired party, as the entity of attention or sympathy.

The friendship between visually impaired and sighted people in this study stems from

Cite this as:

Nurjaman, tabah Aris. Exploring The Interdependence Between Visually Impaired And Sighted People In The Early Phase Of Friendship. Indonesian Journal of Disability Studies (IJDS).2018: Vol. 5(1): PP 115-126 
contacts that result from common activity (similarity) and adjacency (proximity). Frequentative contact gave a presentation space to show personal characteristics, both from the visually impaired or sighted parties in an attempt to get attention from the environment. When one of the parties to make conversation, either reprimand or greeting, then contact a friendship aspect becomes activated. However, activation of the contact does not guarantee the establishment of friendship before the rise in attractiveness on the sighted party and appraisal on the visually impaired party. That is, when the contacts are not active or activated contact but do not bring up attractiveness and appraisal, relations between the two sides will be stagnated in social relations.

The appraisal on visual impairment means to assigns characteristics and identity of sighted partner. This appraisal would open the possibility of visual impairment people to ask for help to sighted partner. In Figure 3.1 the visual impairment people assign characteristics sighted partner will tend to ask for help based factor willingness. That is, when they are already familiar with the characteristics of the partner, indirectly they already know the partner identity. Thus, visual impairment people will have recourse to the sighted partner even if they are far apart geographically. Unlike the case when the blind just memorize the identity of the partner, the demand for assistance is based on availability. This situation indicates that the visual impairment people do not necessarily feel the need for specific assistance sighted partner. As a result, the satisfaction gained temporary, so that visual impairment people become independent in the friendship. Meanwhile, visual impairment individuals who are often asking for help to the sighted partner will gain fundamental satisfaction as friendship investment.

The attractiveness in the sighted people means seeks to know the visual impairment partner and/or to learn more about disability. Both of these motives to encourage them to help the visually impaired partner. However, when it comes in contact passive or active contact but do not foster the attractiveness, then the relationship is not progressive and just happened on the circumference of social relations. Based on Figure 3.1, sighted people who are interested in disability tend to provide aid for sympathy, while sighted people who are interested in the characteristics of visual impairment partner tend to give assistance because they care. Behavioral altruism in sighted individuals can turn to for help when it happens repeatedly. When this happens, the aid is no longer seen as altruism, but rather as an investment in friendship.

The aid distribution on the sighted party and fundamental satisfaction on the visually impaired party is a relational investment that potentially leads to dependence pattern. But when aid distribution in form of altruistic and satisfaction is temporary, then potentially direct relationship into independence pattern. Dependence pattern may arise as a result of ambivalence between the form of help on the sighted party and satisfaction level of visually impaired party. Although at first glance it appears that this relationship can lead to interdependence pattern for their relational investment on both sides, but blindness factor determine relation to the dependence pattern. That is, the need for instrumental help make the visually impaired party vulnerable as the dependent party to their sighted spousal party because of a low degree of interest in instrumental interaction. Thus, a search for interdependence relational pattern does not stop at the early stage of friendship but need more in-depth search at the next stage of friendship.

\section{Discussion}

Friendship is one of the existential human entities as social actors. Dwyer (2002) define friendship as a relationship that is built by individual sincerity, irrespective of the boundaries of age, class, culture or gender. The need for friendship not only serves as a complementary element of visual impairment or disability people but fundamental for every individual. Classic and contemporary psychological theories laid the interpersonal relationship as fundamental needs of individuals in carrying out social functions (see Baumeister, 2012; Lewin, 1936). Thus, the relations of friendship between visually impaired and sighted people not only serves as an antidote to blindness alone but also produce benefits for the sighted in different entities. This view is the proposition that visual impairment people are not always dependent on the sighted friend, but there are chances of their interdependent relationship. 
The friendship between visually impaired and sighted people one built through instrumental assistance. Theoretically, this instrumental assistance is one manifestation of prosocial behaviors do not exist solely in interpersonal relationships. This prosocial behavior can be divided into helping behavior and altruism. Both of these concepts are equally understood as behavior that provides benefits for other individuals, but the altruism emphasizes that helping behavior is not based on personal motives (Dovidio \& Penner, 2003; Faturochman, 2009). Prosocial behavior as the foundation of the friendship between the visually impaired and sighted people can be seen as helping behavior and altruism.

Dovidio and Penner (2003) describes the empathy-altruism hypothesis that altruism likely to produce emotional experiences, such as grief, personal distress such as anger and anxiety, as well as empathy as sympathy and compassion. When the altruism behavior led to grief and personal distress, then the altruism can turn into helping behavior. Thus, this emotional experience indicates the existence of affective aspects in the dyadic relation between the visually impaired and sighted couple of friendship. Based on the theory of investment, the emotional experience such as satisfaction not only strengthen relationships between individuals but also as a manifestation of relational investment that direct to the interdependent pattern of relationship (Rusbult et al., 2012).

The distribution of instrumental aid form sighted party to visually impaired party not only emerged by coincidence but also there have been previously activated contacts as a consequence of similarity (similarity in activity) and proximity (geographic proximity). Theoretically, similarity and proximity factor is the basis for the establishment of friendship (see Dwyer, 2002). However, in the context of friendship between visually impaired and sighted people, both of these factors drove first to the aid distribution stage. Faturochman (2009) explains that helping may also arise because of individual characteristics involved, as their similarities. That is, sighted party tends to help visually impaired party because of the similarity between the two sides. Thus, the instrumental assistance as one of the foundations of friendship between visually impaired and sighted people into logical findings.

According to Nadler and colleagues (2010), the distribution of aid is one of the efforts by individuals to increase self-esteem or to maintain status as a superior side. This view may be valid in the friendship between the visually impaired and sighted couple. That is, the distribution of aid is not only intensified the friendship and benefit the visually impaired party alone but also strengthen self-esteem and feelings of superiority on the sighted party. However, this does not necessarily make the visually impaired as inferior and dependent party. Helping behavior that appears on the progress of friendship means the degree of dependence on the visually impaired is to a minimum degree. This means that the visually impaired party are still more likely to ask for help on the other sighted individual, who is not his sighted partner. This situation indicates that visually impaired and sighted people can be independent of each other even though the relation of friendship have been built. However, the needs of visually impaired people to other individuals because of anatomical blindness (Broman et al., 2002; Camarena, 2013; Good et al., 2008), the lack of accessibility, and obstruction social environment (Hwang et al., 2015; Irwanto et al., 2010; Thohari, 2014), directing them as parties who potentially be dependent on the friendship with the sighted people.

Help acquired the visually impaired people on the progress of friendship can be a material identification friend's partner. At the level of cognition, the visually impaired evaluate the quality of aid it received from the sighted so directing preferences to intensify the relations of friendship or not. Simpson, Fletcher, and Campbell (2003) describe that the ideal partner of relation identified by the relevance of the characteristics of the partner, the personality and appearance of the partner, and the characteristics of social status and resource partner. According to this view, the ideal partner of friend evaluation leads to the relevance of the characteristics of the partner who is sincerely distributing aid to him. This situation confirms that the visually impaired people prioritize relationships with a higher degree of loyalty, rather than focusing on the significance of relations excitement (see Simpson et al., 2003). Thus, the distribution of aid as a foundation of this friendship will produce long-term relationship.

\section{Conclusion}

The friendship between visually impaired 
and sighted people stems from contact which is activated by one of the parties through greetings. This greeting on the visually impaired party becomes the material to memorize and to know the identity of the sighted partner. The sighted party is also trying to know the visually impaired partner as the manifestation of his attractiveness to the partner personality or to the disability world. When the two sides know each other as increasingly frequent interaction, the visually impaired party began to ask for help to the sighted partner on the basis of availability and willingness. Likewise, the sighted party distributes the instrumental aid as a form of sympathy and care for the partner. So then, this kind of situation deliver them to the friendship bond.

Distribution of instrumental aid as the idiosyncratic relationship between visually impaired and sighted people in the early phase of friendship confirms a tendency of dependence pattern. However, those relationships are not static on a particular pattern, but the dynamic between independence, dependence and interdependence patterns. This relationship pattern is determined based on the type of instrumental aid that is distributed by the sighted party between helping or altruism. Unlike the case with the visually impaired party, it is determined based on the requesting for assistance between availability or willingness, as an entity of satisfaction degree.

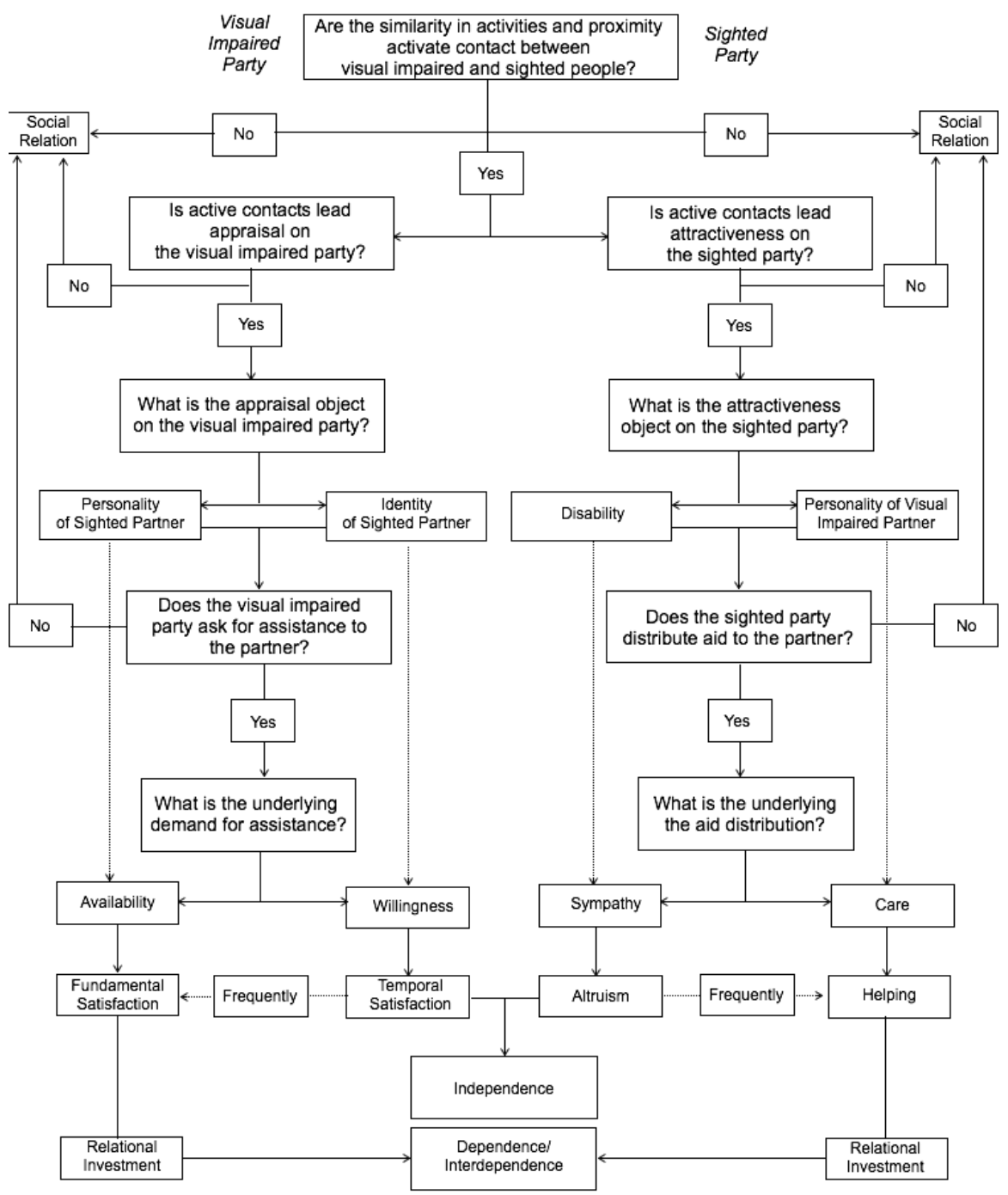

Figure 1 The Model of Friendship Progress Between Visual Impaired a nd Sighted People 


\section{References}

Ainsworth, M. (1969). Object relations, dependency, and attachment: A theoretical review of the infant-mother relationship. Child Development, 40, 969-1025.

Altman, B. (2001). Disability definitions, models, classification schemes, and applications. In G. Albrecht, K. Seelman, \& M. Bury (Eds.), Handbook of disability studies (pp. 97-122). California: Sage Publications.

Asbjornslett, M., Engelsrud, G., \& Helseth, S. (2011). 'Friendship in all directions': Norwegian children with physical disabilities experiencing friendship. Childhood, 19(4), 481494. doi: 10.1177/0907568211428093

Ayomi, A. (2009). Kompetensi interpersonal anak tunanetra di Sekolah Luar Biasa Bagian A (Unpublished undergraduate's skripsi). Universitas Sanata Dharma, Yogyakarta.

Baumeister, R. (2012). Need-to-belong theory. In P. Van Lange, A. Kruglanski, \& E. Higgins (Eds.), Theories of social psychology (Vol. 2, pp. 121-140). London: SAGE Publications.

Berscheid, E., \& Ammazzalorso, H. (2003). Emotional experience in close relationships. In G. Fletcher \& M. Clark (Eds.), Interpersonal processes (pp. 308-330). Oxford: Blackwell Publishers.

Broman, A., Munoz, B., Rodriguez, J., Sanchez, R., Quigley, H., Klein, R., Snyder, R., $\&$ West, S. (2002). The impact of visual impairment and eye disease on vision-related quality of life in a Mexican-American population: Proyecto VER. Investigative Ophthalmology \& Visual Science, 40(11), 3393-3398.

Brown, C., Packer, T., \& Passmore, A. (2013). Adequacy of the regular early education classroom environment for students with visual impairment. Hammill Institute on Disabilities, 46(4), 223-232. doi: $10.1177 / 0022466910397374$

Camarena, V. (2013). Perceptions of older adults with diverse visual impairments about safety, independence, amobility, and social connection (Master's thesis). Available from ProQuest Dissertations and Theses database. (UMI No. 1524180)

Carson, G. (2009). The social model of disability. Scotland: Scottich Accessible Information Forum.

Cascella, P. Trief, E., \& Bruce, M. (2012). Parent and teacher ratings of communication among children with severe disabilities and visual impairment/blindness. Hammill Institute on Disabilities, 33(4), 249-251. doi: $10.1177 / 1525740112448249$

Celeste, M. (2006). Play behaviors and social interactions of a child who is blind: In theory and practice. Journal of Visual Impairment \& Blindness, 100(2).

Creswell, J. (2014). Penelitian kualitatif \& desain riset: Memilih di antara lima pendekatan. (A. Lazuardi, Trans.). Yogyakarta: Pustaka Pelajar. (Original work published 1998)

Crystal, D., Watanabe, H., \& Chen, R. (1999). Children's reactions to physical disability: a cross-national and developmental study. International Journal of Behavioral Development, 23(1), 91-111.

Cuddy, A., Fiske, S., \& Glick, P. (2008). Warmth and competence as universal dimentions of social perception: The stereotype content model and the bias map. Advantaces in Experimental Social Psychology, 40, 61-149. doi: 10.1016/S0065-2601(07)00002-0

Dietrich, S. (2005). A look at friendships between preschool-aged children with and without disabilities in two inclusive classrooms. Journal of Early Childhood Research, 3(2), 193-215. doi: 10.1177/1476718X05053933

Dovidio, J., \& Penner, L. (2003). Helping and altruism. In G. Fletcher \& M. Clark (Eds.), Interpersonal processes (pp. 162-195). Oxford: Blackwell Publishers.

Dwyer, D. (2002). Interpersonal relationships. Philadelphia: Taylor \& Francis.

Cite this as:

Nurjaman, tabah Aris. Exploring The Interdependence Between Visually Impaired And Sighted People In The Early Phase Of Friendship. Indonesian Journal of Disability Studies (IJDS).2018: Vol. 5(1): PP 115-126 
Faturochman. (2009). Pengantar psikologi sosial. Yogyakarta: Penerbit PUSTAKA.

Fichten, C., Goodrick, G., Amsel, R., \& McKenzie, S. (1991). Reactions toward dating peers with visual impairments. Rehabilitation Psychology, 36(3), 163-178.

Fine, M., \& Glendinning, C. (2005). Dependence, independence or interdependence? Revising the concepts of 'care' and 'dependency'. Ageing \& Society, 25, 601621. doi: 10.1017/S0144686X05003600

Gilovich, T., Keltner, D., \& Nisbett, R. (2011). Social psychology (2nd ed.). New York: W.W. Norton \& Company.

Good, G., Logrow, S., \& Alpass, F. (2008). An age-cohort study of older adult with and without visual impairments: Activity, independence, and life satisfaction. Journal of Visual Impairment \& Blindness, 102(9), 517527.

Grass, K. (2010). Relationship between contact and preschoolers attitudes toward peers with disability (Doctoral dissertation). Available from ProQuest Dissertations and Theses database. (UMI No. 3435812)

Gur, K., \& Albayrak, S. (2015). Exposure to violence of secondary school children with visual impairment. Journal of Interpersonal Violence, 1-18. doi: $10.1177 / 0886260515600162$

Hallahan, D., \& Kauffman, J. (2006). Exceptional Learners: Introduction to Special Education (10th ed.). Boston: Pearson Education.

Haslam, N. (2006). Dehumanization: An integrative review. Personality and Social Psychology Review, 10(3), 252-264.

Herlina, Heryati, E., \& Chotidjah, S. (2008). Profil kebutuhan psikologis mahasiswa tunanetra di Fakultas Ilmu Pendidikan Universitas Pendidikan Indonesia (Report No. 217/H.40.8/PL.00.14/2008). Retrieved form Universitas Pendidikan Indonesia website: http://goo.gl/xGrjS4
Herrera, R. (2015). Communication profiles of children with profound visual impairment and their caregiviers (Doctoral dissertation). Available from ProQuest Dissertations and Theses database. (UMI No. 3670571)

Hodge, S., \& Eccles, F. (2013). Loneliness, social isolation and sight loss. Retrieved from Lancaster University, Division of Health Research website: http://goo.gl/T8GDDB

Hwang, A., Yen, C., Liou, T., Simeonsson, R., Chi, W., Lollar, D., Lio, H., Kang, L., Wu, T., Teng, S., \& Chiu, W. (2015). Participation of children with disabilities in Taiwan: The gap between independence and frequency. PLOS One, 10(5), 1-19. doi: 10.1371/journal. pone. 0126693

Irwanto, Kasim, E., Fransiska, A., Lusli, M., \& Okta, S. (2010). Analisis situasi penyandang disabilitas di Indonesia: Sebuah desk-review. Retrieved form Universitas Indonesia, Pusat Kajian Disabilitas website: http://goo.gl/ibho9O

Jindal-Snape, D. (2005a). Self-evaluation and recruitment of feedback for enhanced social interaction by a student with visual impairment. Journal of Visual Impairment and Blindness, 99(8), 1-19.

Jindal-Snape, D. (2005b). Use of feedback from sighted peers in promoting social interaction skills. Journal of Visual Impairment and Blindness, 99(7), 1-16.

Kelly, H., Holmes, J., Kerr, N., Reis, H., Rusbult, C., \& Van Lange, P. (2003). An Atlas of Interpersonal Situations. New York: Cambridge University Press.

Kementerian Kesehatan. (2014). Data dan informasi kesehatan: Situasi penyandang disabilitas. Jakarta: Kementerian Kesehatan Republik Indonesia.

Khadka, J., Ryan, B., Margrain, T., Woodhouse, J., \& Davies, N. (2012). Listening to voices of children with a visual impairment: A focus group study. The British Journal of Visual Impairment, 30(3), 182-196. doi: $10.1177 / 0264619612453105$

Cite this as:

Nurjaman, tabah Aris. Exploring The Interdependence Between Visually Impaired And Sighted People In The Early Phase Of Friendship. Indonesian Journal of Disability Studies (IJDS).2018: Vol. 5(1): PP 115-126 
Khurshid, F., \& Najeeb, F. (2012). Perceived social acceptance among visually impaired teenegers. Pakistan Journal of Education, 29(1), 1-12.

Levin, S., Laar, C., \& Sidanius, J. (2003). The effects of ingroup and outgroup friendships on ethic attitudes in college: A longitudinal study. Group Processes \& Intergroup Relations, 6(1), 76-92.

Lewin, K. (1936). Principles of topological psychology. New York: The McGraw-Hill Book Company.

Lifshitz, H., Hen, I., \& Weisse, I. (2007). Selfconcept, adjustment to blindness, and quality of friendship among adolescents with visual impairment. Journal of Visual Impairment \& Blindness, 101(2), 96-107.

Mahabbati, A. (2014). Kebijakan, implementasi dan isu strategis pendidikan bagi individu berkebutuhan khusus. Jurnal Pendidikan Islam, $3(1), 31-46$.

Meriyani. (2013). Interaksi sosial antara sesama penyandang cacat tunanetra dalam Badan Sosial Mardiwuto (Unpublished undergraduate's skripsi journal). Universitas Negeri Yogyakarta, Yogyakarta.

Morrison, R., \& Burgman, I. (2009). Friendship experiences among children with disabilities who attend mainstream Australian schools. Canadian Journal of Occupational Therapy, 76(3), 145-152.

Moustakas, C. (1994). Phenomenological Research Methods. California: SAGE Publications.

Munniksma, A., Stark, T., Verkuyten, M., Flache, A., \& Veenstra, R. (2013). Extended intergroup friendships within social settings: The moderating role of initial outgroup attitudes. Group Processes \& Intergroup Relations, $16(6), \quad 752-770 . \quad$ doi: $10.1177 / 1368430213486207$

Murniasih, E. (2004). Hubungan interpersonal lawan jenis remaja tunanetra (Unpublished undergraduate's skripsi). UIN Syarif
Hidayatullah, Jakarta.

Nadler, A., Halabi, S., Harapz-Gorodeisky, G., \& Ben-David, Y. (2010). Helping relations as status relations. In M. Mikulincer \& P. Shaver (Eds.), Prosocial Motives, Emotions, and Behavior (pp. 181-200). Washington, DC.: American Psychological Association.

Page-Gould, E., Mendoza-Denton, R., \& Tropp, L. (2008). With a little help from my crossgroup friend: Reducing anxiety in intergroup contexts through cross-group friendship. Journal of Personality and Social Psychology, 95(5), 1080-1094. doi: 10.1037/00223514.95.5.1080

Pettigrew, T. (1998). Intergroup contact theory. Annual Review of Psychology, 49, 65-85.

Pfeiffer, J., \& Pinquart, M. (2011). Attainment of developmental tasks by adolescents with visual impairment and sigtes adolescents. Journal of Visual Impairment \& Blindness, 105(1), 33-44.

Phuspita, F. (2010). Sistem kepercayaan adat kehamilan dan kelahiran dalam masyarakat jawa dalam teks Platenalbum Yogya 30 (Unpublished undergraduate's skripsi).

Universitas Indonesia, Depok.

Pinquart, M., \& Pfeiffer, J. (2011a). Associations of extroversion and parental overprotection with forming relationships with peers among adolescents with and without visual impairment. Journal of Visual Impairment \& Blindness, 105(2), 96-107.

Pinquart, M., \& Pfeiffer, J. (2011b). Bullying in German adolescents: Attending special school for students with visual impairment. The British Journal of Visual Impairment, 29(3), 163-176. doi: 10.1177/0264619611415332

Pinquart, M., \& Pfeiffer, J. (2012). Body image in adolescents with and without visual impairment. The British Journal of Visual Impairment, 30(3), 122-131. doi: $10.1177 / 0264619612458098$ 
Richardson, P. (2002). The school as social sontext: Social interaction patterns of children with physical disabilities. The American Journal of Occupational Therapy, 56(3), 296304.

Roe, J. (2008). Social inclusion: meeting the socio-emotional needs of children with vision needs. The British Journal of Visual Impairment, 26(2), 147-158. doi: 10. $1177 / 0264619607088277$

Rosenblum, L. (1997). Friendship dyads of adolescents with visual impairment (Doctoral dissertation). Available from ProQuest Dissertations and Theses database. (UMI No. 97295353)

Rusbult, C., Agnew, C., \& Arriaga, X. (2012). The investment model of commitment processes. In P. Van Lange, A. Kruglanski, \& E. Higgins (Eds.), Theories of social psychology (Vol. 2, pp. 218-231). London: SAGE Publications.

Rusbult, C., Arriaga, X., \& Agnew, C. (2003). Interdependence in close relationships. In G. Fletcher \& M. Clark (Eds.), Interpersonal processes (pp. 359-387). Oxford: Blackwell Publishers.

Schuh, M., Sundar, V., \& Hagner, D. (2014). Friendship is the ocean: Importance of friendship, acceptance, and leadership in the transition to adulthood. Career Development and Transition for Exceptional Individuals, 110. doi: $10.1177 / 2165143414528031$

Senicar, M., \& Grum, D. (2011). Self concept and social support among adolescent with disabilities attending special and mainstream schools. University of Ljubljana, 48(1), 73-83.

Shakespeare, T., \& Watson, N. (2002). The social model of disability: An outdated ideology? Research in Social Science and Disability, 2, 9-28.

Simpson, J., Fletcher, G., \& Campbell, L. (2003). The structure and function of ideal standards in close relationships. In G. Fletcher $\&$ M. Clark (Eds.), Interpersonal processes (pp. 86-106). Oxford: Blackwell Publishers.
Stevelink, S., Malcolm, E., \& Fear, N. (2015). Visual impairment, coping strategies and impact on daily life: A qualitative study among working-age UK ex-service personnel. BMC Public Health, 15, 1-7. doi: 10.1186/s12889015-2455-1

Sulla, E. (2011). Examining children's attitudes toward disability after one year in a reverse integrated setting (Master's thesis, Concordia University). Retrieved from http://goo.gl/EkoNfi

Thohari, S. (2014). Penyandang disabilitas dan aksesibilitas fasilitas publik bagi penyandang disabilitas di kota Malang. Indonesia Journal of Disability Studies, 1(1), 27-37.

Untari, I., \& Mayasari, S. (2015). Study of developing the myths of pregnancy. University Research Colloquium, 64-72.

Van Lange, P., \& Rusbult, C. (2012). A theory of communal (and exchange) relationships. In P. Van Lange, A. Kruglanski, \& E. Higgins (Eds.), Theories of social psychology (Vol. 2, pp. 251-272). London: SAGE Publications.

Vezzali, L., \& Capozza, D. (2011). Reducing explicit and implicit prejudice toward disabled colleagues: Effects of contact and membership salience in the workplace. Life Span and Disability, 19(2), 139-162.

Wang, C., Chan, C., Ho, A., \& Xiong, Z. (2008). Social networks and health-related quality of life among chinese older adults with vision impairment. Journal of Aging and Health, 20(7), 804-823. doi: $10.1177 / 0898264308321083$

Willig, C. (2008). Introducing Qualitative Research in Psychology. New York: McGraw Hill.

Cite this as:

Nurjaman, tabah Aris. Exploring The Interdependence Between Visually Impaired And Sighted People In The Early Phase Of Friendship. Indonesian Journal of Disability Studies (IJDS).2018: Vol. 5(1): PP 115-126 